\title{
But where is György Dózsa? - are there objective heroes in history?
}

Hanneleena HietA*

\begin{abstract}
In this paper, the author focuses on the controversial life and death of György Dózsa, the sixteenth-century mercenary and leader of a peasant revolt against the upper classes, to address the questions of what is heroism and who gets to define it. Whereas earlier Marxist historians considered him a hero for challenging the rule of the upper classes (while at the same time ignoring his upper-class background), twenty-first century historiography has omitted him from the pantheon of Hungarian national heroes. This omission is highlighted most clearly in Opusztaszer National Historical Memorial Park near Szeged in south-eastern Hungary, a region claiming to be the place where the Hungarian state was born. The statues erected to commemorate one thousand years of Hungarian statehood did not include György Dózsa; instead, they commemorate those figures who best symbolized the stability of the state. Internal dissent does not make for good national heroes.
\end{abstract}

Key words: Hungarian history, memorial places, heritage sites, historiography, sponsoring.

What is ÓPUSzTASzer National Historical Memorial Park?

We, an international team of ethnographers, were doing field work in the Ópusztaszer National Historical Memorial Park in the summer of 2005. A visitor, looking at the memorial circle of great Hungarian historical figures, had posed a question: Where is György Dózsa? This is indeed a valid question, one which I will address in a short while. But first, I must answer two other questions: What is Ópusztaszer National Historical Memorial Park? And, who was György Dózsa?

Hungary is an interesting exception to most nation-states in Europe, in the sense that Hungarian historiography can tell exactly when the Magyars (ethnic Hungarians) entered the Carpathian basin. As it is such a focal point of historiography, there are, naturally, a variety of theories when it comes to the absolute date, population numbers and ethnic constitution of the groups that entered, 
Hanneleena Hieta

126

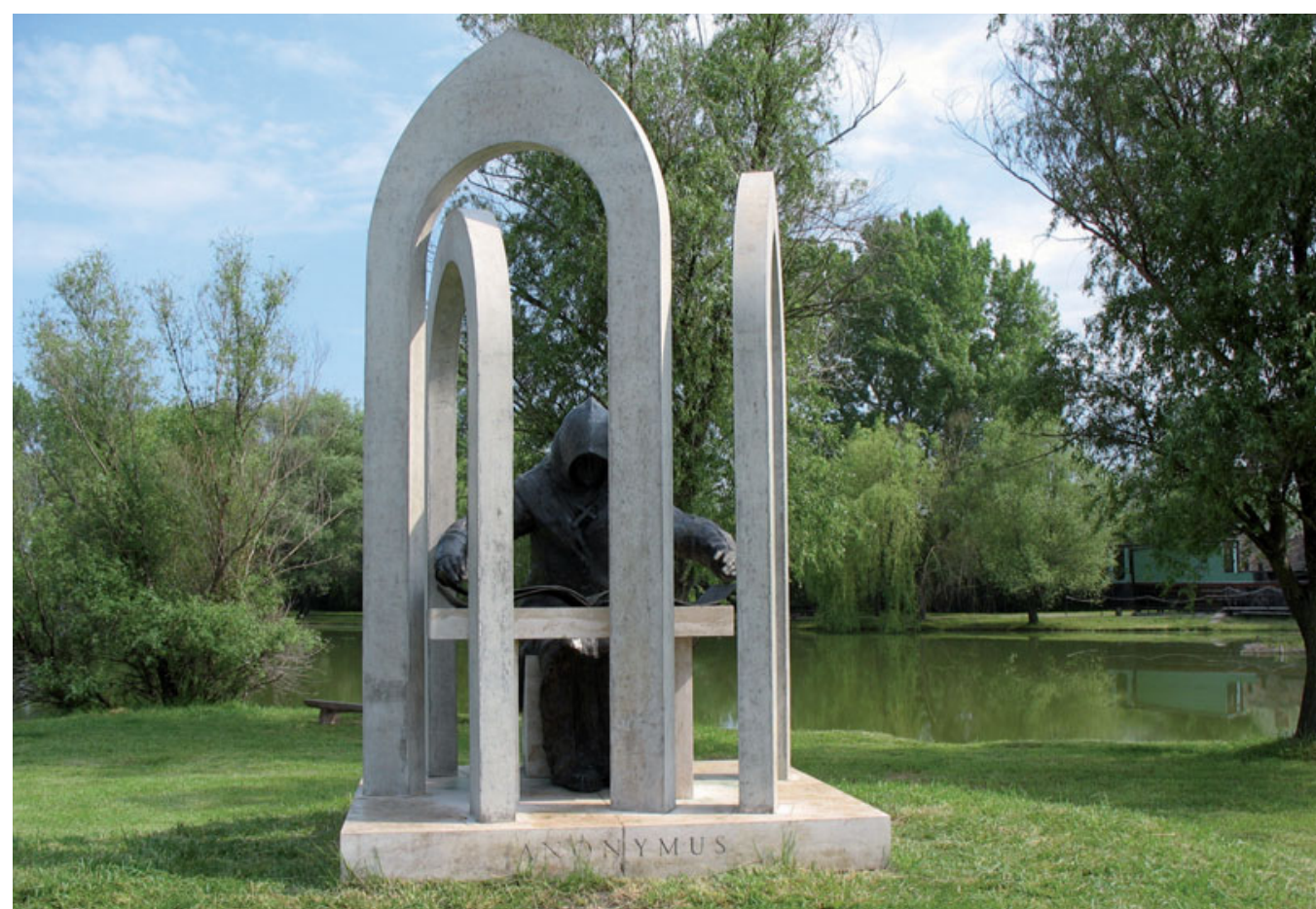

A statue of Anonymous. Photo: Hanneleena Hieta 2006.

and the nature of the occupation - whether it was by "conquest" or a more peaceful settlement. But we know with certain clarity that around the years 895 and 896 the Magyars did occupy the Carpathian basin. They were, at that point, a tribal society. They practiced agriculture, even though they also had a nomadic lifestyle. We even know that the name of their tribal leader was Árpád. (Kontler 2002: 42-50, passim.)

Approximately one hundred years later, in the year 1000, the mediaeval Hungarian kingdom was established, and the development henceforth led to a typical feudal society with peasants and overlords. At that point, it also became meaningful to show a pedigree that dated back to the time of the occupation. And this is the point at which a scribe we now know by the name Anonymus (which, of course, means that we do not know his name) wrote a chronicle of the Hungarian occupation. Naturally, this piece of literary work had political ends: it was written to support the leading families of the thirteenth century and legitimize their power. (Kontler 2002: 72.) In fact, all through history the noble families legitimized their power by referring to their Magyar ancestry. The notion that peasants were ethnic Hungarians came about much later. (Hofer 1991: 159; Sinkó 1994: 16-17.) The literary work of Anonymus was eventually forgotten and not re-discovered 


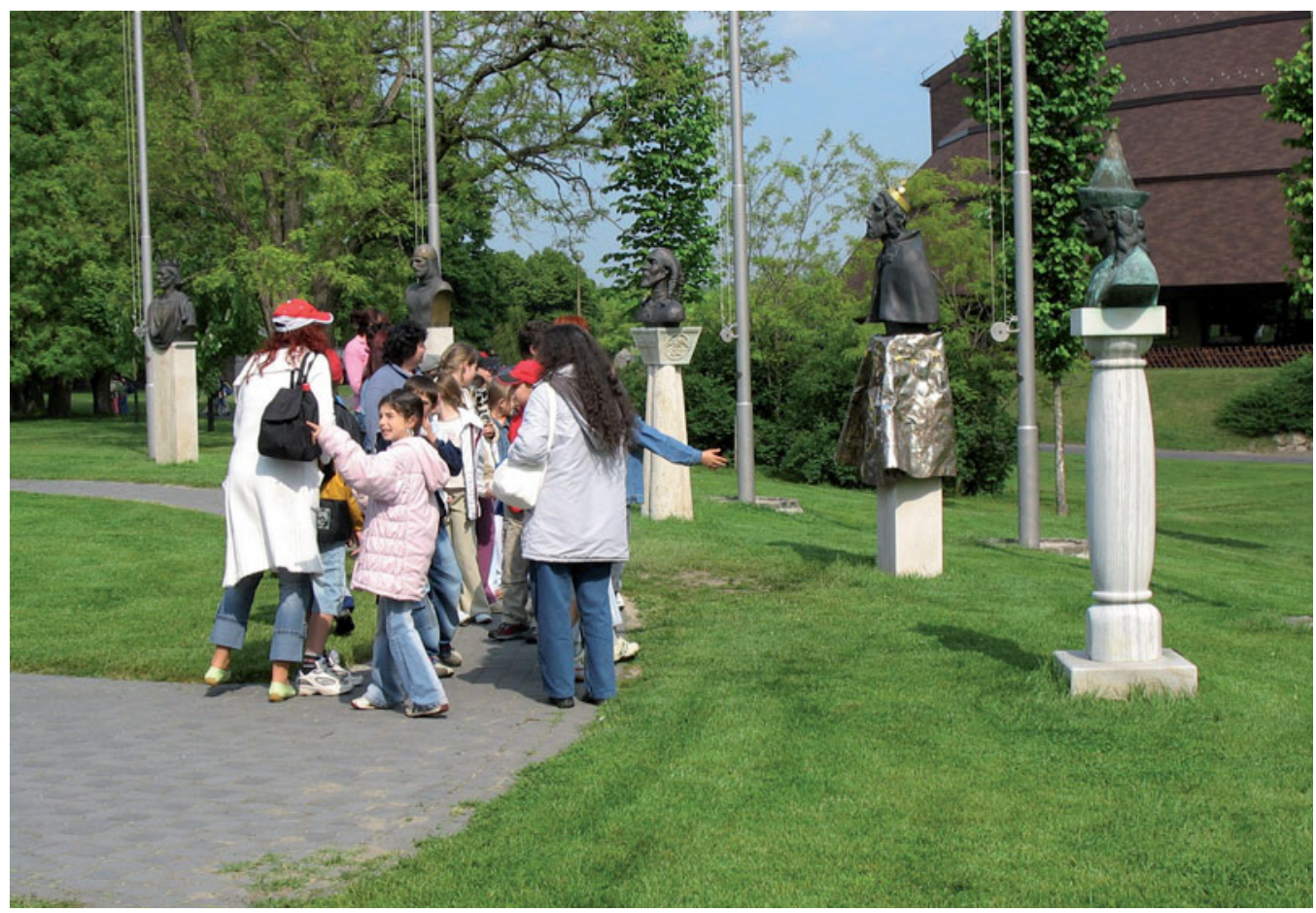

Visitors at the memorial for thousand years of Hungarian statehood. Photo: Hanneleena Hieta 2006.

until the eighteenth century, when it kindled a very different national imagination.

Anonymus's chronicle mentions that the Magyar tribes held a gathering in a place where they later built the town and monastery of Szer. In this gathering, the tribal leaders decided which tribe was to occupy which particular area of the Carpathian basin. However, by the eighteenth century, and especially by the nineteenth century, when the chronicle was translated into Hungarian, it was to serve a different purpose. The legend gained a completely different meaning in a kingdom that was awakening nationally after hundreds of years being divided into three parts and under the rule of the non-indigenous
Habsburg monarchy. The area near Szer, which at that time was practically uninhabited (the town and monastery had disappeared during the Turkish occupation), gained new interest.

The first modern initiative to build some kind of a memorial in the area near Szer came from the head accountant of the town of Kecskemét almost immediately after the chronicle had been translated into Hungarian, at the beginning of the 1860s. In 1883, the priest of Pusztaszer, Benedek Göndöcs, suggested that a memorial chapel could be built there. This was in connection with the nationwide preparations for the Hungarian millennium festivities that were planned for 
128 the year 1896. Interestingly, in the millennium year two monuments were raised in the area. The rival provincial towns of Szeged and Kecskemét both raised their own respective monuments. Szeged had the advantage in that the site of the Szer monastery was within its jurisdiction. The nineteenth-century village of Pusztaszer, which by its name was the successor to the town of Szer, was situated relatively far from it. Pusztaszer belonged within Kecskemét's jurisdiction. The residents of Kecskemét had their own monument, a proud obelisk with the silhouettes of the seven tribal leaders and the mythic Turul bird on top, raised on a mound that was at that point renamed the Árpád mound. The monument by the people of Szeged was unveiled in June 1896, when it was still unfinished, but it still attracted many thousands of visitors both from nearby areas and from the capital. The monument is classic in form and has a statue of Árpád on top. The monument near the monastery ruins of Szer gained a lot more attention in the following years. It became the site for an annual pilgrimage festival, and therefore the obelisk on the mound near Pusztaszer became less important. (Sinkó 1996, 9-11; Zombori \& Trogmayer 1980, 139; Vályi \& Zombori 2000, 12; Savolainen 2005, 145-146.)

In 1936, the Árpád Society, the custodian of the Árpád monument, rented property around the monument in order to create a memorial park with the name Árpád National Park. The following year an artesian well was drilled in the park and named Árpád's Well. The year after that, a large wooden gate in the style of the Transylvanian Szekler (Székely) peasants was erected at the entrance to the park. There were plans to build a memorial chapel and a memorial museum in the park, but these plans were interrupted by the Second World War (Vályi \& Zombori 2000, 72).

Right at the end of the Second World War, the new government took steps to end the plight of the landless rural population by dividing the large estates of the nobility into smaller plots. The symbolical weight of Szer became obvious in that the land reform was started right there. The lands of the Pallavicini estate were the first to be divided. More than three thousand peasants came to witness the event. This historical moment was labelled in the political speeches held there as the second Hungarian division of land. The first one was naturally that of Árpád and the Hungarian tribes in 896 (Sinkó 1996, 12; Vályi \& Zombori 2000, 196). The minister Imre Nagy became known among the people as the landdivider minister (Kontler 2002, 395).

The old tradition of annual pilgrimages was still held in 1946 and 1948. After that, it became impossible. The dictatorship of Rákosi did not accept either the national sentiment or the private ownership of land. Hence, there was nothing worth memorializing in Szer. In 1957, as the political clock had again moved a little forward for Hungary, the gathering was allowed once again, but it was referred to as a "peasant-worker get-together", as the idea of a pilgrimage would not have been accepted. Thousands of people showed up again and the gathering became an annual event (Vályi \& Zombori 2000, 72-74). The political speeches by high-level Communist politicians formed the intellectual core of the gatherings, but plenty of eating and other entertainment may well have been the more important part of the event.

In 1970, the plans for the park, which were dropped at the beginning of the Second World 
War, moved forward. The popular sociologist, politician and head of the Patriotic People's Front, Ferenc Erdei, suggested that the ancient history of the Szer area should be documented by archaeological excavations and that the area should become a monument for the history of the Hungarian state. He voiced an opinion that instead of nationalism it should be a place for positive national self-knowledge and pride (Erdei 1970, 173-174). Csongrád County and the Patriotic People's Front started to develop the park. The president of the republic, Pál Lozonczi, was the chairman of the memorial committee in the years 1977-1989. This ensured state funding for the park (Vályi \& Zombori 2000, 74; Szabó G. 1995, 5). Extensive archaeological excavations began as early as 1970 and lasted until 1975. An open-air ethnographical village museum was built alongside a large exhibition hall, which was to host a cyclorama painting by Árpád Feszty. The painting dated to the Hungarian millennium and depicted the Hungarian conquest of the Carpathian basin. It demanded a lot of restoration, which took years. As the park was a combined effort of the People's Front and the county, it was natural that the scientific contents of the park were created and supervised by the local county museum. The Ópusztaszer National Historical Memorial Park was born and it formed a branch of the county museum (Savolainen 2005, 154-158).

The development of the park as a branch of the county museum reached a turning point in 1995. As we know, Hungary went through a period of political transition at the beginning of the 1990s. The public sector spending in the last decade of socialism had become unsustainable and drastic cuts had to be made. This affected the museum sector as well as many other public services in the 129 country. The public money needed for preparing the Ópusztaszer National Historical Memorial Park for the Hungarian Millecentenarium (1996) became a political hot potato. The county government made a decision to cut the park off from the county museum system and develop it as an independent entity. Henceforth, the park had to earn what it spent. Legally speaking, it was made into an enterprise for public benefit (közhasznú társaság). In numbers, the park had to attract between 300,000 and 350,000 visitors annually to make ends meet. In the beginning, this was easy: the Feszty cyclorama was a major attraction. It had gained massive publicity, and opinions varied in terms of being either for or against its nineteenthcentury national sentiment, but in any case everybody wanted to see it. In 2000, when I interviewed one of the directors of the park, it had become obvious that the popularity of the cyclorama had already started to fade. The park needed sponsor money, which came in the form of direct sponsorship and new, sponsored monuments (Hieta 2010, 190- 193; Pálfy 1995, 26-28). The historical survey presented above answers my first question. Now I need address the second one concerning the person of György Dózsa.

\section{WHO WAS GYÖRGY DÓZSA AND WHY IS HE ABSENT?}

In April 1514, Pope Leo X sent a papal bull to Buda in order to organize a crusade against the Ottomans. Within a short time, approximately forty thousand peasant crusaders had gathered in camps near Pest. György Székely Dózsa was the officer appointed to be in charge of the campaign. The nobility was against the 
Hanneleena Hieta

130

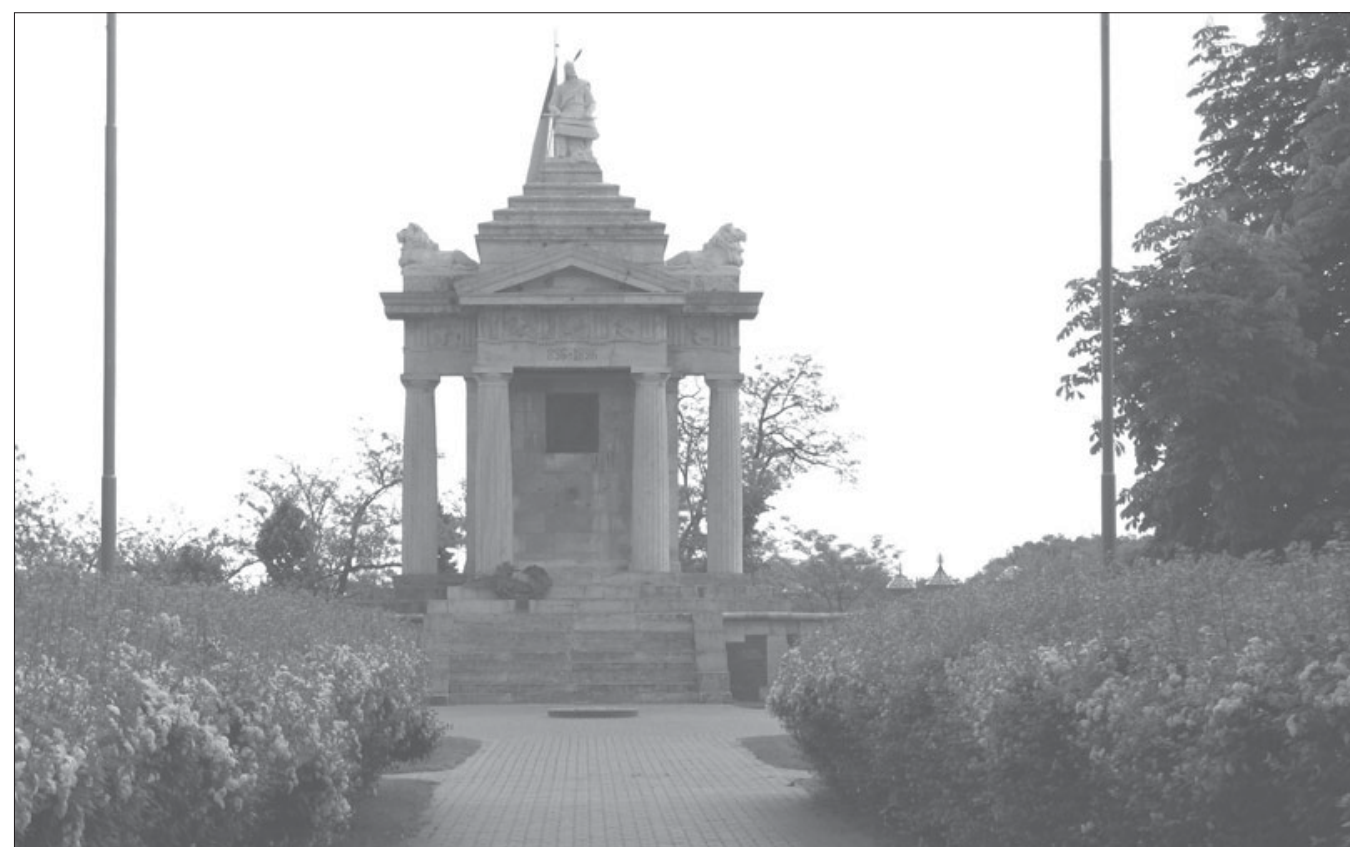

The Arpád memorial. Photo: Hanneleena Hieta 2006.

peasant crusade because they did not want the labour force to leave their estates. Soon the crusade turned into a revolt of the peasant class, whose social standing had worsened over the previous decades as the landlords had constantly demanded more and more day labour. The peasants demanded similar freedoms as the Szeklers (Székely) of Transylvania. The revolt did not last long. Dózsa and his army surrendered in July 1514. György Dózsa was executed in the cruellest manner. He was made to sit on a red-hot iron throne, wearing a burning hot iron crown and sceptre. His associates were forced to eat his flesh. As collective punishment against the peasants, the Hungarian Diet passed legislation which subjected peasants to 'eternal servitude'. This meant fully fledged feudalism. The law was in fact not changed until as late as 1848 (Kontler 2002: 133-134).

It goes without saying that the tragic character of György Dózsa has been an inspiration to many pieces of artistic expression from poetry to opera and from art to drama. A street named after him can be found in most cities and towns in Hungary. His portrait was also on the former Hungarian 20 Forint bank note. For Marxist historians, he was the perfect embodiment of class struggle. Naturally, his upper class origins were more or less ignored and the peasant struggle against the overlords was emphasized. To anybody who went to school prior to the political changeover, the name Dózsa must have become engraved in their memory as one of the most significant characters of mediaeval Hungarian history. 
So, to return to the foot of the Árpád memorial, we were looking at a circle of twenty great names of Hungarian history. They were as follows: chief Géza, Saint Stephen, Sámuel Aba, Andrew I, Béla I, Saint Ladislas, Béla III, Andrew II, Béla IV, Ladislas (Cumanian) IV, Louis the Great, Sigismund of Luxemburg, János Hunyadi, King Matthias I, István Báthory, István Bocskai, Ferenc Rákóczi II, Count Lajos Batthyány, Count István Széchenyi and Lajos Kossuth. (http:// www. opusztaszer.hu/index.php/page/emlekhelyek_ alkotasok.html.) The first ten of them were from the house of Árpád. From Louis the Great to Ferenc Rákóczi II, we saw other leaders of the kingdom, in part from the time when only Transylvania stood for independent Hungary. Batthyány, Széchenyi and Kossuth were the great politicians of the emergent modern Hungary in the 1800 s. In this display of the succession of political power there was no space for a short-term peasant revolt leader named György Dózsa.

What exactly was going on at the monument? According to the Ópusztaszer website:

Local administrative authorities from the counties in Hungary donated the 20 busts you can see here to commemorate the millennium of the establishment of the Hungarian State. The President of the Hungarian Republic inaugurated the busts on June 30th 2001. The pantheon of busts creates a spiritual arch over 10 centuries in the history of Hungary bridging the events of the Hungarian Conquest and the tragic end of the War of Independence in 1848-1849.

(http://www. opusztaszer.hu/index.php/page/ emlekhelyek_alkotasok.html)

When I interviewed one of the directors of the park in 2000, he told me that the number of statues was limited to exactly 20 because that is the number of counties in Hungary. (There are 19 counties and Budapest.) The idea was that each county donated one statue. The statues were to be inaugurated at the 4th National Meeting of the County Governments, which was going to take place the following June. He added that since 45 per cent of the visitors to the park are "school-going youth", it is important to let them know the main lines of Hungarian history, also in the form of statues. My following question was: Who decided which are the 20 most important figures in Hungarian history? It was the director himself, with the help of the professors of history at the University of Szeged. (TYKL/spa/148/u:9.)

The purpose of the circle of historical figures is crystal clear: to celebrate the Hungarian nation, which in 2001 was exactly one thousand years old, if we count the years starting from the coronation of Hungary's first king, St. Stephen. The institution that was celebrating, in this case, was the county government system, which, in its own way, saw itself as a successor to the Hungarian throne (as Hungary has for a long time been a democratic republic). It makes sense then that the first kings are those of the House of Árpád. It also makes sense that some of the leaders by necessity have to be Transylvanian, as at certain times in history it was the only independent part of Hungary. It also makes sense that after the reign of Ferenc Rákóczi II (1704-1711) we jump directly to the emerging modern Hungarian state and thus omit a century of Habsburg rule.

The reason why György Dózsa is absent is obvious. On the one hand, when there are only 20 spots to fill and we have to tell the story of a thousand years of uninterrupted 
132 Magyar history, there is no space for a shortterm peasant rebellion. Interestingly, the Magyar pedigree still rests on the shoulders of the nobility. On the other hand, we have to remember how sponsorship influences these types of decisions. The whole story of the statues came up in the interview at the point when we were discussing sponsorship. It is an interesting question whether the pantheon of great Hungarian historical figures would have been different if there had not been exactly 20 spots to fill and 20 local county governments to appease. But was the park visitor wrong in asking about György Dózsa? Even though "class struggle" is a Marxist term and Marxism is out of fashion, it is still a valid question. Why don't memorial places commemorate all historical strata of society? One of the answers may be that it is so much easier to talk about struggles to establish national independence than to remember the internal conflicts of interest.

\section{BIBLIOGRAPHY}

Erdei Ferenc: Város és vidéke. Szépirodalmi könyvkiadó: Budapest 1971.

Hieta, Hanneleena: Mukautuva museo, kolmen eurooppalaisen kansanelämänmuseon muutostarina 1970-luvulta 2000-luvun alkuun. University of Turku: Turku 2010.

Hofer, Tamás: "Construction of the 'Folk Cultural Heritage' in Hungary and Rival Versions of $\mathrm{Na}$ tional Identity". Ethnologia Europaea 21, (1991): 145-170.

Kontler, László: A History of Hungary, Millennium in Central Europe. Palgrave Macmillan: Basingstoke 2002.

Pálfy Katalin: “ 'Minden Magyar jöjjön el Ópusztaszerre - életében legalább egyszer...' Összefoglaló a Nemzeti Történeti Emlékpark Országos Emlék- bizottsága és a Feszty-körkép Alapítvány Kuratoriuma üléseir1 l". Szeged 3/1995, 25-28.

Sinkó, Katalin: "Árpád versus Saint István. Competing Heroes and Competing Interests in the Figurative Representation of Hungarian History". Tamás Hofer (ed.) Hungarians between "East" and "West". Three Essays on National Myths and Symbols. Museum of Ethnography: Budapest 1994.

Sinkó Katalin: "Pusztaszer ürügyén: emlékhely, kiállítás és idegenforgalom”. Ujj müvészet 8/1996, 4-17, 71-75.

Szabó G. László 1995. "Az ópusztaszeri Országos Emlékbizottság története”. Magyar múzeumok 2/1995, 5-6.

Vályi Katalin \& Zombori István: Ópusztaszer. A Szász magyar falu könyvesháza Kht: Budapest 2000.

Zombori István \& Trogmayer Ottó: Szer monostorától Ópusztaszerig. Magvet1 Kiadó: Budapest 1980.

\section{OTHER SOURCES}

\section{E-source}

http://www.opusztaszer.hu/index.php/page/emlekhelyek_alkotasok.html

\section{Archival sources}

University of Turku, Department of Cultural Research Archives: An interview transcript, TYKL/spa/148/u:9

Savolainen [Hieta], Hanneleena: Museo pustalla. Tapaustutkimus kansatieteellisestä museotoiminnasta Unkarissa. Lisensiaatintutkimus. Turku: Turun yliopisto 2005.

*Hanneleena Hieta, PhD

Address: European Ethnology, FI-20014 University of Turku, Finland.

E-mail: Hanneleena.hieta@gmail.com 